E-SELECTIN (CD62E) is an endothelial specific glycoprotein belonging to the selectin family of adhesion molecules. Because a high expression of this molecule at intestinal mucosal surfaces in inflammatory bowel disease (IBD) has been described earlier, the aim was to assess serum levels of E-selectin (sE-selectin) and to correlate it to disease activity, and further to evaluate its chemotactic properties at physiological concentrations. Levels of $\mathrm{SE}$ selectin were measured by a sandwich ELISA technique in 31 IBD patients together with 15 healthy volunteers. In ulcerative colitis the median value was $0.46 \mathrm{nM}$ $(0.16-0.75)$, in Crohn's disease $0.47 \mathrm{nM}(0.22-1.24)$, and in healthy controls $0.34 \mathrm{nM}(0.22-0.83)$. No statistically significant differences in $\mathrm{sE}$-selectin were revealed between these groups $(p>0.05)$. The in vitro chemotactic capabilities of E-selectin (in the concentration range of 0.10-31.4 nM) were assessed using the leading front technique. A significantly increased migratory response was found at concentrations of $1.00(p<0.05)$ and $3.14 \mathrm{nM}$ $(p<0.02)$. It is concluded that sE-selectin in contrast to sICAM-1 does not act as a sensitive indicator of local immune activation in IBD. However, E-selectin may be important for recruitment and accumulation of neutrophilic granulocytes and other phagocytes involved in the inflammatory process seen in IBD. Future investigations are encouraged in order to reveal its in vivo effects.

Key words: Cell adhesion molecules, Chemotaxis, Crohn's disease, E-selectin, Monoclonal antibodies, Ulcerative colitis, Vascular endothelium

\section{Serum concentration and chemotactic activity of E-selectin (CD62E) in inflammatory bowel disease}

\author{
B. Vainer ${ }^{\mathrm{CA}}$ and $\mathrm{O}$. H. Nielsen
}

Department of Medical Gastroenterology C, Herlev Hospital, University of Copenhagen, Herlev Ringvej, DK-2730 Herlev, Denmark

CA Corresponding Author

\section{Introduction}

The pathogenesis of the inflammatory bowel diseases (IBD), i.e. ulcerative colitis (UC) and Crohn's disease (CD), is not yet clarified. Among the mediators which in the view of recent research are thought to be of importance for the pathogenesis of these diseases are the adhesion molecules, and among them E-selectin (CD62E) (previously named ELAM-1, endothelial-leucocyte adhesion molecule-1) with a molecular weight of $115 \mathrm{kDa}$.

The E-selectin molecule is normally not present on the surfaces of vascular endothelial cells, but in vitro investigations have revealed that stimulation with certain cytokines (i.e. interleukin-1, tumour necrosis factor- $\alpha$, lipopolysaccharides, substance $P$, and interferon- $\gamma$ ) induces production and expression of $\mathrm{E}$ selectin on surfaces of such cells. ${ }^{1-7}$ The amount of Eselectin increases shortly after stimulation with these cytokines, whereas it decreases after stimulation for $16-24 \mathrm{~h}^{4-7}$ On the contrary, stimulation with TNF- $\alpha$ continuously increases production of E-selectin.? After epicutaneous provocation for $2 \mathrm{~h}$ in vivo with chemicals known to be antigenic in susceptible patients, E-selectin is expressed on the luminal membrane of the vascular endothelial cells. E-selectin amounts to a peak level in approximately $24 \mathrm{~h}$, and then decreases. ${ }^{8}$

E-selectin mediates the binding between endothelial cells, particularly to neutrophilic granulocytes (PMNs), ' but also to basophilic and eosinophilic granulocytes. ${ }^{3}$ It also mediates binding to monocytes ${ }^{9,10}$ as well as to a sub-group of T cells $\left(\mathrm{CLA}^{+}\right)$and certain strains of tumour cells. ${ }^{9,11,12}$ E-selectin has a chemotactic effect, and the activity of E-selectin in vitro is crucial for the migration of granulocytes across endothelial monolayers. ${ }^{9,13}$

E-selectin is detectable at the luminal membranes of endothelial cells in active IBD but not in inactive IBD or in healthy volunteers. ${ }^{14}$ Accordingly, electron microscopy has shown E-selectin to be exocytosed into the vascular lumen. ${ }^{15}$ Therefore, it has been suggested that E-selectin is both a transmembrane protein and a secretory protein.

Antibodies to the E-selectin ligand, sLe ${ }^{\mathrm{x}}$, have been shown to react with venous endothelia of the inflamed appendix ${ }^{16}$ and an analogous mechanism of E-selectin directing leukocytes to inflamed bowel segments may occur in IBD.

The aims of this study was to examine: (1) if E-selectin was present in serum from IBD patients and whether this concentration correlates to disease 
activity, and (2) the chemotactic properties of Eselectin on PMNs.

\section{Patients and methods}

Patients: Plasma from 31 consecutive patients with well established IBD ( 16 with $\mathrm{UC}^{17}$ and 15 with $\mathrm{CD}^{18}$ ), seen in the out-patient clinic, and 15 healthy volunteers, all aged 18-75 years, were studied for Eselectin content using ELISA methods. None had received glucocorticoids within the preceding 4 weeks, and none was colectomized. Patients with known auto-immune diseases or other chronic inflammatory conditions were excluded. Disease activity was scored according to Tvede et al., ${ }^{19}$ modified according to Langholz et al. ${ }^{17}$ and Munkholm et al.,$^{18}$ by the number of bowel movements per day, the presence of blood, mucus and pus in the stools, abdominal pain, and general symptoms such as malaise, weight loss, fever, and symptoms from joints, skin and eyes (Table 1). Essential clinical parameters are given in Table 2. All patients apart from six (three with UC and three with CD) were treated with 5-aminosalicylic acid-containing drugs (1-4 g/day). Blood from eight healthy volunteers was obtained for purification of PMNs to be used in a chemotactic assay.

ELISA: Serum E-selectin (sE-selectin) was analysed by a sandwich enzyme linked immunoassay (ELISA) (R\&D Systems Europe Ltd, Abingdon, UK). In brief, two E-selectin monoclonal antibodies, recognizing different epitopes of the E-selectin molecule, were precoated onto polystyrene microtitre wells. Stand-

Table 1. Criteria for determination of inflammatory bowel disease (IBD) activity Symptoms

\begin{tabular}{|c|c|c|c|c|}
\hline \multirow[t]{2}{*}{ Symptoms } & \multicolumn{4}{|c|}{ IBD activity } \\
\hline & Inactive & Mild & Moderate & Severe \\
\hline $\begin{array}{l}\text { Bowel movements } \\
\text { per day }\end{array}$ & $\leq 2$ & $3-4$ & $\geq 5$ & $\geq 5$ \\
\hline Blood, mucus, pus* & - & < Daily & Daily & Daily \\
\hline Abdominal pain & - & - & Mild & Frequent \\
\hline $\begin{array}{l}\text { Extraintestinal } \\
\text { symptoms }\end{array}$ & - & - & Few & Many \\
\hline
\end{tabular}

ards or diluted samples were then placed in the wells followed immediately by addition of an enzyme conjugated E-selectin monoclonal antibody. Eselectins in serum or standards were bound to the coating antibody, while the conjugated antibody was bound to another distinct epitope on captured Eselectin. A chromogen solution was added to the wells forming a coloured end product, proportional to the amount of E-selectin in the samples. A conjugate of streptavidin and horseradish peroxidase (Streptavidin-HRP Conjugate, R\&D Systems) was used to catalyse this process. The concentration of sE-selectin (nM) was measured by use of a standard curve based on six known concentrations of recombinant E-selectin and an ELISA reader at an absorption of $450 \mathrm{~nm}$ (EAR 400, SLT Labinstruments, Salzburg, Austria). Absorption at $630 \mathrm{~nm}$ was used for reference. The detection limit was $8.7 \mathrm{pM}$, and the coefficient of variation 0.5 . According to the manufacturer, both monoclonal antibodies were raised specifically against the E-selectin molecule.

Isolation of neutrophils: Peripheral blood was drawn in EDTA (0.2 M). Purification of PMNs was in all cases initiated within $30 \mathrm{~min}$ after blood was drawn. After a methylcellulose sedimentation of erythrocytes and haemolysis, leukocytes were washed three times and re-suspended in Gey-albumin solution (2\%) at a concentration of $2 \times 10^{6}$ cells $/ \mathrm{ml}$. The final cell suspension contained approximately $80 \%$ PMNs, recovery was $70 \%$, and viability after chemotaxis more than $95 \%$.

Chemotaxis: E-selectin antigen $(200 \mu \mathrm{g} / \mathrm{ml})$ in PBS (R\&D Systems Europe Ltd), Gey's solution, casein (Hammersten, Merck, Darmstadt, Germany), and millipore filters ( $3 \mu \mathrm{m}$ pore size, thickness $140 \mu \mathrm{m}$ in dry condition) (Sartorius, 25N, type SM11302, Göttingen, Germany) were used in the chemotactic assay. E-selectin antigen was diluted with Gey's solution into the following concentrations: $0.10,0.31$, $1.00,3.14,10.0$, and $31.4 \mathrm{nM}$. Boyden chambers with cell suspension and E-selectin suspension separated by nitro-cellulose filters were incubated at $37^{\circ} \mathrm{C}$ for $45 \mathrm{~min}$. Median migratory responses were assessed by the leading front technique, and were based on the analysis of five randomly selected fields as described previously in detail. ${ }^{20}$ To estimate spon-

Table 2. Clinical parameters of patients with chronic inflammatory bowel diseases

\begin{tabular}{lccccccc}
\hline Subjects & No. & $\begin{array}{c}\text { Age } \\
\text { (years) }\end{array}$ & Sex & & \multicolumn{2}{c}{ Disease activity } \\
\cline { 5 - 7 } & & & & Inactive & Mild & Moderate & Severe \\
\hline Healthy controls & 15 & $45(36-60)$ & $12 \mathrm{~F}, 3 \mathrm{M}$ & - & - & - & - \\
Ulcerative colitis & 16 & $37(18-75)$ & $11 \mathrm{~F}, 5 \mathrm{M}$ & 5 & 4 & 5 & 2 \\
Crohn's disease & 15 & $42(22-63)$ & $9 \mathrm{~F}, 6 \mathrm{M}$ & 2 & 2 & 6 & 5 \\
\hline
\end{tabular}

*Medians are given with ranges in brackets. 
taneous migration (chemokinesis), control experiments were carried out in which PMNs in Gey's solution migrated towards Gey's solution alone (negative control). All results of E-selectin chemotaxis were corrected for chemokinesis. In addition, a positive control was assessed with PMNs in Gey's solution and compared with casein.

Ethics: Informed consent was obtained before blood samples were drawn in accordance with the Second Helsinki Declaration. The study was approved by the Scientific Ethical Committee of Copenhagen County.

Statistics: Non-parametric statistics (medians and ranges) and Mann-Whitney's rank sum test were applied. A $p$ value less than $0.05(2 \alpha)$ was considered statistically significant.

\section{Results}

Serum E-selectin: The median serum concentration of E-selectin was in UC $0.46 \mathrm{nM}(0.16-0.75)(p>0.05)$ and in CD $0.47 \mathrm{nM}(0.22-1.24)(p>0.05)$ compared with healthy volunteers $0.34 \mathrm{nM}(0.22-0.83)$. Fig. 1 shows sE-selectin concentrations in IBD patients with different disease stages. No correlation to disease activity was revealed $(p>0.05)$. An increase in the concentration of serum E-selectin in IBD patients could not be demonstrated after stratification for sex, age, number of bowel movements per day, presence of blood, mucus and pus in the stools, abdominal pain and presence of extraintestinal symptoms.

Chemotaxis assays: The chemotactic effect of E-selectin on peripheral PMNs expressed as the migration in $\mu \mathrm{m} / 45 \mathrm{~min}$ is shown in Fig. 2. Corrected for chemokinesis, the cell migration ranged from -36 to

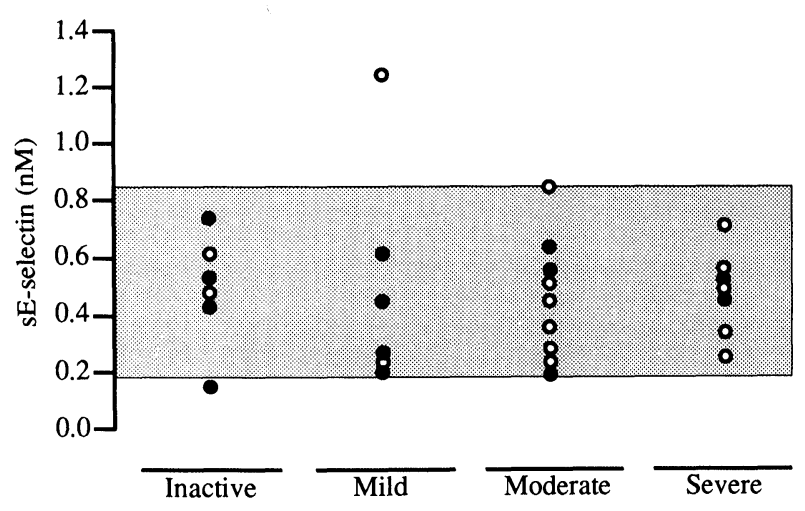

FIG. 1. Concentration of serum E-selectin ( $\mathrm{nM}$ ) among patients with chronic inflammatory bowel diseases, divided on disease activities. The reference range (15 healthy volunteers) is shown (shaded area). Ulcerative colitis $(\bullet)$ and Crohn's disease (O). The median values were $0.46 \mathrm{nM}$ for inactive, $0.35 \mathrm{nM}$ for mild, $0.53 \mathrm{nM}$ for moderate, and $0.49 \mathrm{nM}$ for severe UC; and $0.53 \mathrm{nM}$ for inactive, $0.74 \mathrm{nM}$ for mild, $0.37 \mathrm{nM}$ for moderate, and 0.41 for severe $C D$. The median value for controls was $0.34 \mathrm{nM}$.

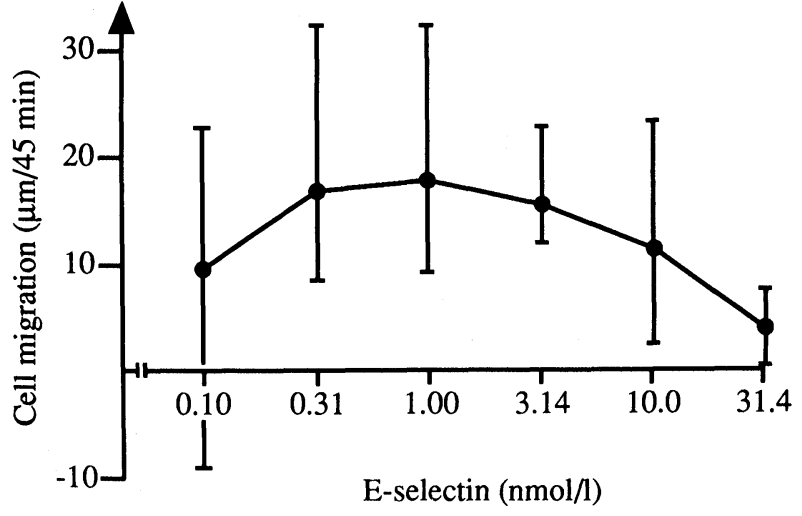

FIG. 2. Chemotactic effect of recombinant E-selectin on PMNs in healthy volunteers given as migration in $\mu \mathrm{m}$. Medians and 25/75 percentiles are shown. For the concentration $31.4 \mathrm{nmol} / \mathrm{l} n=5$, for the others $n=8$. The migration ranged from -36.0 to $28.0 \mu \mathrm{m}$ (at $0.10 \mathrm{nM}$ E-selectin); from -18.0 to $36.5 \mu \mathrm{m}(0.31 \mathrm{nM})$; from -36.0 to $58.0 \mu \mathrm{m}(1.00 \mathrm{nM})$; from 7.0 to $28.0 \mu \mathrm{m}$ $(3.14 \mathrm{nM})$; from -12.0 to $27.0 \mu \mathrm{m}(10.0 \mathrm{nM})$; and from -24.0 to $37.0 \mu \mathrm{m}$ (31.4 nM).

$58 \mu \mathrm{m}$ in $45 \mathrm{~min}$. Migration had a peak at an Eselectin concentration of $1.00 \mathrm{nM}$. A significantly increased migratory response corrected for chemokinesis was seen at $1.00 \mathrm{nM}(p<0.05)$ and $3.14 \mathrm{nM}$ $(p<0.02$, Mann-Whitney's test), whereas at other concentrations no statistically significant differences were detected.

With regard to the inter-assay variation, a negative value of migration indicated that the spontaneous migration and the E-selectin directed migratory response were identical.

\section{Discussion}

E-selectin has previously been shown to be expressed on the surface of vascular endothelia in a variety of pathological processes located with other tissues, e.g. skin, liver, kidney, gingiva and arteries. ${ }^{8,21-24}$ However, none of the included IBD patients had such coexisting diseases.

The results suggest that the sE-selectin concentration is not increased in IBD, and it is therefore likely that sE-selectin in itself is not sufficient to induce and maintain the inflammatory response in IBD. However, it is possible that E-selectin is secreted into the blood stream during acute phases of inflammation and thereby may be involved in the accumulation of PMNs at the inflamed intestinal areas in IBD.

The IBD patients included were allowed to continue 5-aminosalicylic acid treatment. However, the sE-selectin concentrations in six patients not receiving 5-aminosalicylic acid (one with inactive UC, five with moderate or severe IBD) ranged from 19.1 to $70.4 \mathrm{nM}$. These patients, however, did not influence the overall results. Thus, it is unlikely that 5-aminosalicylic acid may influence E-selectin production.

Paraclinical parameters such as orosomucoid ( $\alpha_{1}$ acid glycoprotein) and haemoglobin are included in 
the disease activity index described by Tvede et $a l .{ }^{19}$ However, these criteria were not used in our study, as the blood concentration of E-selectin was related only to clinical parameters.

Because a correlation between sE-selectin and disease activity was lacking, sE-selectin cannot be used as an activity marker in IBD. This in contrast to the recent findings that SICAM-1 is significantly increased in active IBD $(355 \mathrm{ng} / \mathrm{ml})$, compared with inactive IBD $(310 \mathrm{ng} / \mathrm{ml})$ and controls $(245 \mathrm{ng} / \mathrm{ml})(p=0.00002){ }^{25}$ Within the different activity stages, a considerable inter-individual variation of E-selectin concentration was found. Further, a large inter-individual variation was seen in healthy volunteers, confirming observations by Fuggle et al..$^{22}$ in transplanted kidneys.

The chemotactic activity of PMNs in our assay was elicited with physiological levels of E-selectin. The concentrations of $\mathrm{sE}$-selectin were in the range of 0.16 to $1.24 \mathrm{nM}$, and at these concentrations a chemotactic effect on PMNs was found. The chemotactic effect of recombinant E-selectin has previously been analysed by Lo et al. ${ }^{26}$ at 10-1 $000 \mathrm{nM}$, showing maximum chemotactic effect at approximately $100 \mathrm{nM}$. Lo et $a .^{26}$ did not find any chemotactic effect at concentrations of E-selectin below $10 \mathrm{nM}$. The present study has revealed such an activity even at concentrations of $0.10 \mathrm{nM}$, and a significant chemotactic effect was seen at $100 \mathrm{nM}$. Probably, this is due to methodological differences since larger pore size filters $(3 \mu \mathrm{m})$ were used compared with those used by Lo et al. ${ }^{26}$, who used $2 \mu \mathrm{m}$ pore sizes.

From both the present and other results, ${ }^{24}$ it is evident that E-selectin by acting with the dual function of transmembrane receptor protein and circulating protein may direct PMNs to inflamed segments in IBD.

Further research on adhesion molecules in IBD patients must be carried out on patients without other known diseases. To avoid a possible influence of anti-inflammatory drugs, investigations should be performed on newly diagnosed IBD patients before initiation of specific anti-inflammatory treatment. Additionally, in vivo studies of the ability of Eselectin to direct leukocytes across the vascular endothelial cell lining are needed.

\section{References}

1. Kuijpers TW, Hakkert BC, Hoogerwerf M, Leewenberg JFM, Roos D. Role of endothelial leukocyte adhesion molecule-1 and platelet-activating factor in neutrophil adherence to IL-1-prestimulated endothelial cells. J Immunol 1991; 147 1369-1376.

2. Cronstein BN, Weissmann G. The adhesion molecules of inflammation. Arth Rheum 1993; 36: $147-157$

3. Bochner BS, Luscinskas FW, Gimbrone MA. Adhesion of human basophils, eosinophils, and neutrophils to interleukin 1-activated human vascular endothelial cells: contributions of endothelial cell adhesion molecules. J Exp Med 1991; 173 1553-1556.
4. Luscinaskas FW, Brock AF, Arnaout MA, Gimbrone MA. Endothelial-leukocyte adhesion molecule-1-dependent and leukocyte (CD11/CD18)-dependent mechanisms contribute to polymorphonuclear leukocyte adhesion to cytokine-activated human vascular endothelium. J Immunol 1989; 142: 2257-2263.

5. Matis WL, Lavker RM, Murphy GF. Substance P induces the expression of an endothelial-leukocyte adhesion molecule by microvascular endothelium. $J$ Invest Dermatol 1990; 94: 492-495.

6. Vidal MJ, Zocchi MR, Poggi A, Pellegatta F, Chierchia SL. Involvement of nitric oxide in tumour cell adhesion to cytokine-activated endothelial cells. J Card Pharm 1992; 20(suppl 12): 155-159

7. Bevilacqua MP, Pober JS, Mendrick DL, Cotran RS, Gimbrone MA. Identification of an inducible endothelial-leukocyte adhesion molecule. Proc Natl Acad Sci USA 1987; 84: 9238-9242

8. Friedmann PS, Strickland I, Memon AA, Johnson PM. Early time course of recruitment of immune surveillance in human skin after chemical provocation. Clin Exp Immunol 1993; 91: 351-356.

9. Hakkert BC, Kuijpers TW, Leewenberg JFM, van Mourik JA, Roos D. Neutrophil and monocyte adherence to and migration across monolayers of cytokine-activated endothelial cells: the contribution of CD18, ELAM-1, and VLA-4. Blood 1991; 78 2721-2726.

10. Leeuwenberg JFM, Jeunhomme TMAA, Buurman WA. Role of ELAM-1 in adhesion of monocytes to activated human endothelial cell. Scand J Immunol 1992; 35 335-341.

11. Damle NK, Eberhardt C, van der Vieren M. Direct interaction with primed CD4 $\mathrm{CD} 45 \mathrm{R}^{+}$memory $\mathrm{T}$ lymphocytes induces expression of endothelial leukocyte adhesion molecule-1 and vascular cell adhesion molecule-1 on the surface of vascular endothelial cell. Eur J Immunol 1991; 21: 2915-2923.

12. Shimizu Y, Newman W, Gopal TV et al. Four molecular pathways of $T$ cell adhesion to endothelial cells: roles of LFA-1, VCAM-1, and ELAM-1 and changes in pathway hierarchy under different activation conditions. J Cell Biol 1991; 113: 1203-1212.

13. Carlos T, Kovach, Schwartz B et al. Human monocytes bind to two cytokineinduced adhesive ligands on cultured human endothelial cells: endothelialleukocyte adhesion molecule-1 and vascular cell adhesion molecule-1. Blood 1991 79: 2266-2271.

14. Koizumi M, King N, Lobb R, Benjamini C, Podolsky DK. Expression of vascular adhesion molecules in inflammatory bowel disease. Gastroenterology 1992; 103 840-847.

15. Ohtani $\mathrm{H}$, Nakamura $\mathrm{S}$, Watanabe $\mathrm{Y}$, et al. Light and electron microscopic immunolocalization of endothelial leucocyte adhesion molecule-1 in inflammatory bowel disease. Virch Arch A, Pathol Anat 1992; 420: 403-409.

16. Munro JM, Lo SK, Corless C, et al. Expression of sialyl-Lewis X, an E-selectin ligand, in inflammation, immune processes, and lymphoid tissues. Am J Pathol 1992; 141 1397-1408.

17. Langholz E, Munkholm $\mathrm{P}$, Nielsen $\mathrm{OH}$, Kreiner S, Binder V. Incidence and prevalence of ulcerative colitis in Copenhagen county from 1962 to 1987. Scand J Gastroenterol 1991; 26: 1247-1256.

18. Munkholm P, Langholz E, Nielsen $\mathrm{OH}$, Kreiner S, Binder V. Incidence and prevalence of Crohn's disease in the county of Copenhagen, 1962-87: a sixfold increase in incidence. Scand J Gastroenterol 1992; 27: 609-614.

19. Tvede M, Bondesen S, Nielsen $\mathrm{OH}$, Rasmussen SN. Serum antibodies to Bacteroides species in chronic inflammatory bowel disease. Scand J Gastroenterol 1983; 18 403-409.

20. Nielsen $\mathrm{OH}$, Elmgreen J. Activation of neutrophil chemotaxis by leukotriene $\mathrm{B}_{4}$ and 5-hydroxyeicosatetraenoic acid in chronic inflammatory bowel disease. Scand J Clin Lab Invest 1987; 47: 605-611.

21. Steinhoff G, Behrend M, Schrader B, Duijvestijn AM, Wonigeit K. Expression patterns of leukocyte adhesion ligand molecules on human liver endothelia. $\mathrm{AmJ}$ Pathol 1993; 142: 481-488.

22. Fuggle SV, Sanderson JB, Gray DW, Richardson A, Morris PJ. Variation in expression of endothelial adhesion molecules in pretransplant and transplanted kidneys -correlation with intragraft events. Transplant 1993; 55: 117-123.

23. Krugluger W, Lill W, Nell A, Katzensteiner S, Sperr W, Förster O. Lectin binding to chronic inflammatory gingival tissue: possible adhesion mechanisms based on lectin-carbohydrate interactions. J Periodont Res 1993; 28: 145-151.

24. van der Wal AC, Das PK, Tigges AJ, Becker AE. Adhesion molecules on the endothelium and mononuclear cells in human atherosclerotic lesions. Am J Pathol 1992: 141: 1427-1433.

25. Nielsen $\mathrm{OH}$, Langholz E, Hendel J, Brynskov J. Circulating soluble intercellular adhesion molecule-1 (ICAM-1) in active inflammatory bowel disease. Dig Dis Sci 1994 (in press).

26. Lo SK, Lee S, Ramos RA, et al. Endothelial-leukocyte adhesion molecule 1 stimulates the adhesive activity of leukocyte integrin CR3 (CD11b/CD18, Mac-1, $\alpha_{m} \beta$ ) on human neutrophils. J Exp Med 1991; 173: 1493-1500.

ACKNOWLEDGEMENTS. The authors are grateful to Richard McGuire, R\&D System Europe Ltd, for the donation of E-selectin antigen, and to Birgit Dejbjerg and Hanne Kargaard for skilful technical assistance.

\section{Received 24 February 1994;}

accepted 14 March 1994 


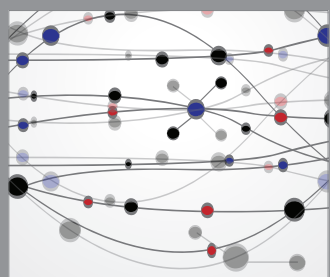

The Scientific World Journal
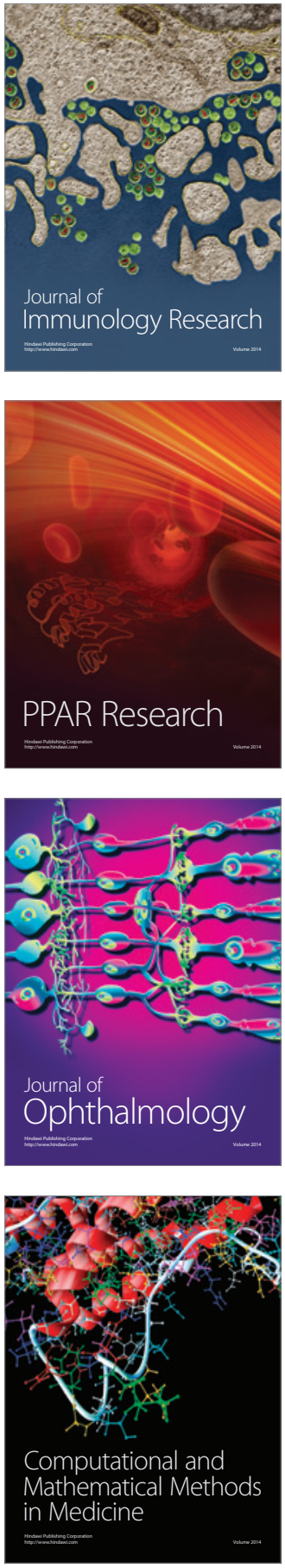

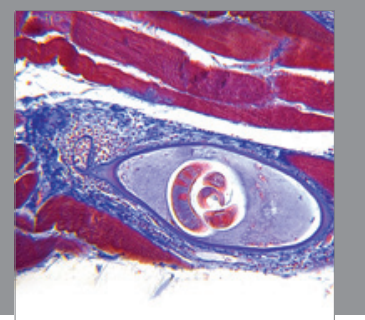

Gastroenterology

Research and Practice
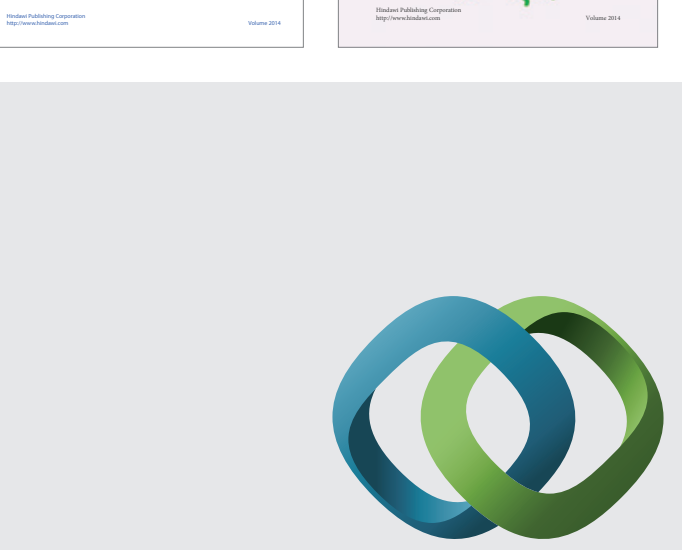

\section{Hindawi}

Submit your manuscripts at

http://www.hindawi.com
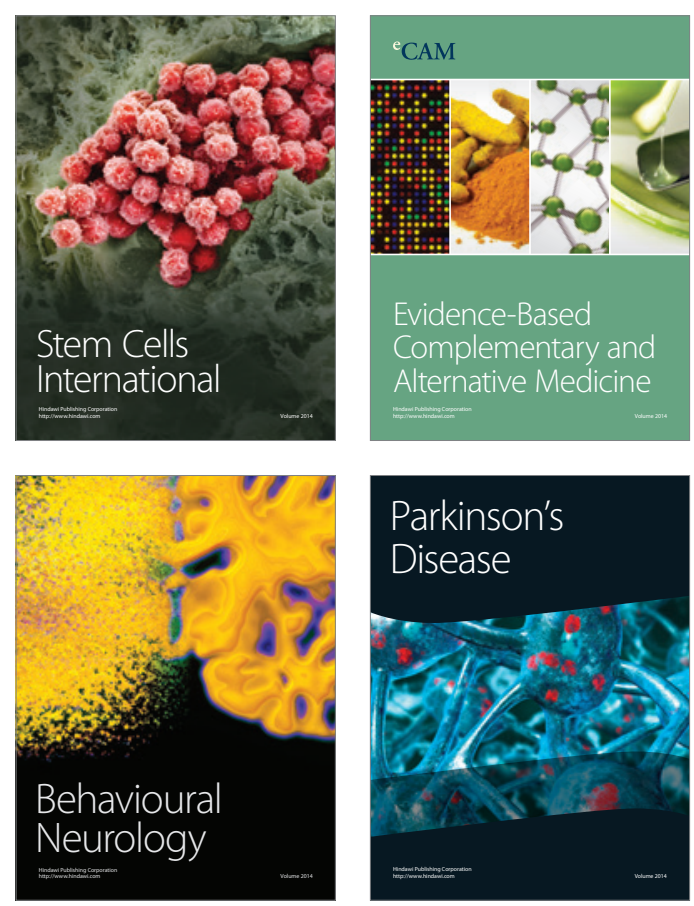

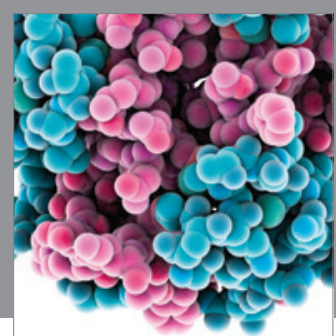

Journal of
Diabetes Research

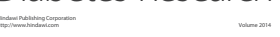

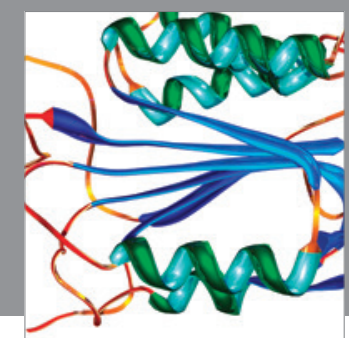

Disease Markers
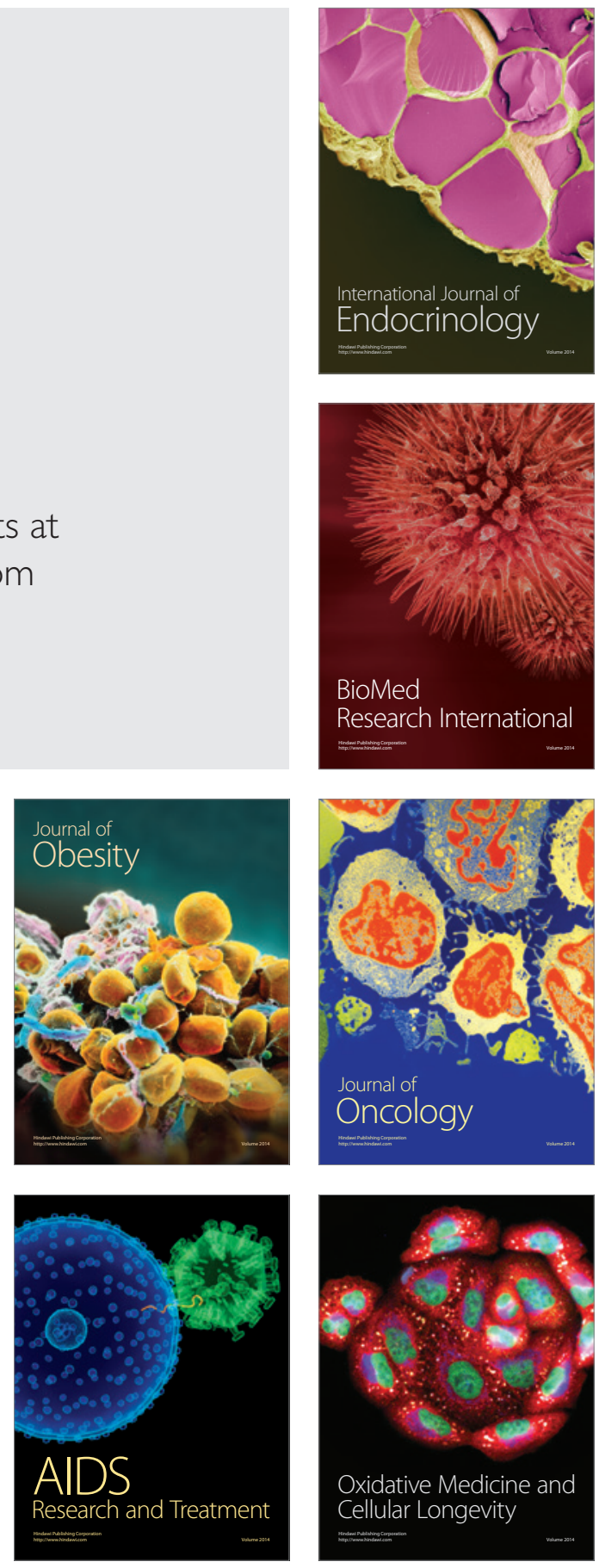